EUROPA REGIONUM TOM XXIII ROK 2015

DOI: $10.18276 /$ er.2015.23-15

EWA MAZUR-WIERZBICKA

Uniwersytet Szczeciński

\title{
Zaspokojenie potrzeb ekoturysty w zakresie przyrodniczym w województwie zachodniopomorskim
}

\section{Wprowadzenie}

D ogarszający się stan środowiska naturalnego, wyczerpywalność zasobów - to główne elementy, które stanowily przyczynek do powstania najbardziej rozpowszechnionej zarówno w drugiej połowie XX wieku, jak też obecnie koncepcji koncepcji zrównoważonego rozwoju. Koncepcja ta została włączona także do tak istotnej dziedziny, jaką jest turystyka. Dało to podstawy do powstania turystyki zrównoważonej, której trzon stanowi ekoturystyka. Skierowanie się społeczności ku działaniom chroniącym środowisko przyrodnicze znalazło swoje odzwierciedlenie m. in. w wyodrębnieniu się szczególnego rodzaju turysty - ekoturysty.

Wobec powyższych przesłanek w artykule skupiono się na ukazaniu fundamentalnych dla ekoturysty walorów - walorów przyrodniczych - województwa zachodniopomorskiego, co stanowi zasadniczy cel artykułu. Jego realizacji podporządkowany został układ pracy. Przybliżono zatem istotę ekoturystyki, zaprezentowano profil ekoturysty, ukazano walory przyrodnicze województwa zachodniopomorskiego. W pracy wykorzystano literaturę przedmiotu, jak również wtórne dane statystyczne.

\section{Ekoturystyka - zagadnienia wprowadzające}

Przybliżając istotę ekoturystyki w pierwszej kolejności należy zwrócić uwagę na wyodrębnienie w obszarze turystyki - turystyki alternatywnej, której pojęcie zaproponował J. Krippendorf w 1987 r. Turystyka alternatywna stanowiła 
opozycję dla turystyki masowej. Charakteryzuje się ona $\mathrm{m}$. in. samodzielną organizacją wyjazdów przez małe nieformalne grupy, które nastawione są głównie na kontakt z miejscową ludnością, obcowanie z rodzimą kulturą odwiedzanych terenów (z zachowaniem tradycyjnych wartości i społeczności) ${ }^{1}$ oraz poznanie odwiedzanego regionu. Zaliczane do niej formy turystyki mają na celu przysparzanie korzyści wszystkim współuczestniczącym. Jednocześnie dążą do minimalizacji szkód gospodarczych, społecznych i ekologicznych ${ }^{2}$.

Należy podkreślić, iż w literaturze przedmiotu występują różne ujęcia definicyjne turystyki alternatywnej, jak też zróżnicowane są kryteria jej wyodrębnienia ${ }^{3}$. Podkreśla się natomiast, że w jej ramach można wydzielić kilka form turystyki, takich jak np. turystyka zrównoważona, której trzon stanowi ekoturystyka, będąca jednocześnie najbardziej idealną jej formą ${ }^{4}$ W przypadku ekoturystyki ważnym jest podkreślenie, że nie jest ona tożsama z turystyką przyrodniczą gdyż bazuje zarówno na zasobach i walorach przyrodniczych, jak też na autentycznych wartościach lokalnej kultury ${ }^{5}$. Może mieć ona charakter poznawczy, samorealizacyjny ${ }^{6}$. Jej specyfika polega $\mathrm{m}$. in. na tym, iż uprawiana jest w małych grupach zaangażowanych osób. Za ważne dla ekoturystyki miejsca należy uznać parki krajobrazowe, obszary chronionego krajobrazu, jak też inne obszary nieobjęte żadną formą ochrony, ale posiadające znaczące walory przyrodnicze.

Pojęcie ekoturystyki sformułował meksykański badacz H. Ceballos-Lascuraina w latach 80. XX wieku. Według niego ekoturystyka związana była z podróżowaniem do niezniszczonych i niezanieczyszczonych naturalnych obszarów przyrodniczych celem poznawania specyfiki środowiska przyrodniczego i kulturowego ${ }^{7}$.

Tak jak w przypadku turystyki alternatywnej, tak też w odniesieniu do ekoturystyki do dziś występuje problem z jednoznacznym jej zdefiniowaniem. Przykładowe definicje terminu ekoturystyka zawarto w tabeli 1.

${ }^{1}$ Z. Kruczek, Obstuga ruchu turystycznego, Proksenia, Kraków 2004.

2 J. Krippendorf, Tourism in the system of industrial society, „Annals of tourism research” 1996, nr 13 (4).

${ }^{3}$ Obstuga ruchu turystycznego, red. B. Meyer, Wydawnictwo Naukowe PWN, Warszawa 2006.

${ }^{4}$ D. Zaręba, Ekoturystyka, Wydawnictwo Naukowe PWN, Warszawa 2008.

${ }_{6}^{5}$ Ibidem.

${ }^{6}$ A. Machnik, I. Miedzińska, Ekoturystyka jako forma aktywizacji terenów wiejskich, w: „Polityka turystyczna, red. A. Panasiuk, Fundacja na rzecz Uniwersytetu Szczecińskiego, Szczecin-Kopenhaga 2005.

${ }^{7}$ D. Weaver, Ecotourism as Mass Tourism: Contradiction or Reality? „Cornell Hotel and Restaurant Administration Quarterly,,, Ithaca, USA, Vol. 42, Cornell University 2001; R.K. Blamey, Principles of Ecotourism, w: The Encyclopedia of Ecotourism, red. D.B. Weaver, Wallingford, UK, CABI Publishing 2003. 
Tabela 1

\begin{tabular}{|l|l|}
\multicolumn{1}{|c|}{ Wybrane ujęcia definicyjne ekoturystyki } \\
\hline \multicolumn{1}{|c|}{ Autor } & \multicolumn{1}{c|}{ Definicja } \\
\hline $\begin{array}{l}\text { Światowa Organizacja } \\
\text { Turystyki }\end{array}$ & $\begin{array}{l}\text { wszystkie bazujące na naturze formy podróżowania, w których } \\
\text { główną motywacją turysty jest obserwowanie natury i uznanie jej } \\
\text { za dobro powszechne }\end{array}$ \\
\hline $\begin{array}{l}\text { The International Ecot- } \\
\text { ourism Society - TIES }\end{array}$ & $\begin{array}{l}\text { odpowiedzialne podróżowanie do obszarów niemal niedotkniętych } \\
\text { działalnością człowieka, które musi uwzględniać wymogi ochrony } \\
\text { przyrody oraz dobro miejscowej ludności, które zachowuje i chroni } \\
\text { środowisko oraz polepsza warunki życia lokalnych mieszkańców }\end{array}$ \\
\hline D. Zaręba & $\begin{array}{l}\text { podróżowanie przyjazne środowisku, które odbywa się zwykle na } \\
\text { obszarach atrakcyjnych przyrodniczo i krajobrazowo }\end{array}$ \\
\hline R. Denman & $\begin{array}{l}\text { podróżowanie w celu studiowania, podziwiania i czerpania za } \\
\text { dowolenia z piękna krajobrazów, obserwacji dzikich zwierząt i roślin, } \\
\text { jak również podziwiania miejscowych obyczajów i kultury }\end{array}$ \\
\hline
\end{tabular}

Źródło: opracowanie na podstawie: D. Diamantis, A. Ladkin, The Links Between Sustainable Tourism and Ecotourism: A definitional and operational perspective, "Journal of Sustainable Tourism" 1999, Vol. 10, No. 2.; S. Blangy, A few concepts and definitions, „Naturopa” 1997; Critical issues in Ecotourism: Understanding a complex tourism phenomenon, red. J. Higham Esevier 2008; D. Zaręba, Ekoturystyka, Wydawnictwo Naukowe PWN, Warszawa 2008.; J. Kamieniecka, (Eko) turystyka zielonym rynkiem pracy, z. 6., Instytut na rzecz ekorozwoju, Warszawa 1995.

Ekoturystyka wyróżnia się spośród innych form podróżowania tym, iż jest formą aktywnego i dogłębnego zwiedzania obszarów o wybitnych walorach przyrodniczych i kulturowych. Dodatkowo strzeże harmonii ekosystemów przyrodniczych i odrębności kulturowej lokalnych społeczności, jak również dostarcza środków finansowych wspomagających skuteczną ochronę wartości dziedzictwa przyrodniczego i kulturowego oraz przynosi realne korzyści ekonomiczno -społeczne miejscowej ludności ${ }^{8}$.

Za podstawowe cechy ekoturystyki uznać zatem należy:

- dogłębne poznawanie obszarów recepcyjnych o wybitnych walorach przyrodniczych i/lub kulturowych;

- zapewnienie harmonii ekosystemów przyrodniczych i odrębności lokalnych społeczności;

- wzrost poziomu wiedzy i świadomości ekologicznej;

- budowanie poparcia dla idei ochrony przyrody;

- dostarczanie wymiernych korzyści ekonomicznych lokalnym społecznościom;

- niewielka skala - brak negatywnego oddziaływania na szeroko pojęte środowisko.

${ }^{8}$ D. Zaręba, op. cit. 
W przeciagu kilku ostatnich lat obserwuje się wzrost zainteresowania ekoturystyką. Uwarunkowane jest to głównie: wzrostem świadomości ekologicznej, w tym pragnieniem, aby być postrzeganym przez innych jako osoba przyjazna dla środowiska przyrodniczego; medialną prezentacją naturalnych obszarów z całego świata; chęcią zobaczenia istniejących jeszcze terenów cennych przyrodniczo; wyczerpaniem się formuły tradycyjnych produktów i atrakcji turystycznych; pragnieniem przeżycia wakacji będących wyzwaniem, ale także pogłębiających świadomość i wiedzę turysty9 ${ }^{9}$.

\section{Profil ekoturysty}

Osoby uprawiające ekoturystykę nazywane są ekoturystami. Przywiązują one dużą wagę do kwestii związanych z ochroną środowiska, posiadają z reguły wysoki, bądź bardzo wysoki stopień świadomości ekologicznej. Według opisu osób-turystów pod względem ich poziomu świadomości ekologicznej zawartego w tabeli 2 klasyfikują się oni do grup: szarozielonych, zielonych oraz jaskrawozielonych.

Tabela 2

Grupy konsumentów-turystów w zależności od poziomu świadomości ekologicznej

\begin{tabular}{|c|c|c|}
\hline Typ konsumenta & $\begin{array}{l}\text { Poziom } \\
\text { świadomości } \\
\text { ekologicznej }\end{array}$ & Cechy charakterystyczne \\
\hline Czarny & $\begin{array}{l}\text { niski poziom } \\
\text { świadomości } \\
\text { ekologicznej }\end{array}$ & $\begin{array}{l}\text { brak wiedzy i świadomości ekologicznej, nieoszczędnie } \\
\text { użytkuje energię, wodę, gaz, prąd elektryczny etc. }\end{array}$ \\
\hline Szary & $\begin{array}{l}\text { średni poziom } \\
\text { świadomości } \\
\text { ekologicznej }\end{array}$ & $\begin{array}{l}\text { niski poziom wiedzy, oszczędza zasoby z przyczyn eko- } \\
\text { nomicznych (jest to najliczniejsza grupa konsumentów) }\end{array}$ \\
\hline Szarozielony & $\begin{array}{l}\text { wysoki poziom } \\
\text { świadomości } \\
\text { ekologicznej }\end{array}$ & $\begin{array}{l}\text { znaczna wiedza ekologiczna, podatność na podniesienie } \\
\text { świadomości ekologicznej, oszczędza zasoby z przyczyn } \\
\text { ekonomicznych lub snobistycznych }\end{array}$ \\
\hline Zielony & $\begin{array}{l}\text { bardzo wysoki } \\
\text { poziom } \\
\text { świadomości } \\
\text { ekologicznej }\end{array}$ & $\begin{array}{l}\text { duża wiedza ekologiczna, stale pogłębiana świadomość } \\
\text { ekologiczna, oszczędne użytkowanie zasobów w celu ich } \\
\text { ochrony, chce zmienić i zmienia swój styl życia, aby } \\
\text { chronić środowisko }\end{array}$ \\
\hline Jaskrawozielony & $\begin{array}{l}\text { bardzo wysoki } \\
\text { poziom } \\
\text { świadomości } \\
\text { ekologicznej }\end{array}$ & $\begin{array}{l}\text { stwarza zagrożenie „zielonego totalitaryzmu”, postuluje } \\
\text { powrót do natury, bardzo oszczędny w użytkowaniu } \\
\text { zasobów }\end{array}$ \\
\hline
\end{tabular}

Źródło: opracowano na podstawie: G. Kobyłko (red.), Proekologiczne zarzadzanie przedsiębiorstwem, Wydawnictwo Akademii Ekonomicznej we Wrocławiu, Wrocław 2000; D. Zaręba, Ekoturystyka, Wydawnictwo Naukowe PWN, Warszawa 2008.

${ }^{9}$ Ecotourism and other Services Derived From Forests in the Asia-Pacific Region: Outlook to 2010, FAO, www.fao.org/docrep/w7714e/w7714e00.htm\#Contents. 
Ekoturyści to osoby wrażliwe i świadome, wymagające w stosunku do siebie i innych. Są oni zorientowani na kontakt z przyrodą oraz atrakcje kulturowe, czemu towarzyszyć ma czyste, przyjazne otoczenie. Generują zysk pozostający w regionie ${ }^{10}$. Za D. Zarębą przyjąć można, iż są to w znacznym stopniu przedstawiciele tzw. generacji EKO - mieszkańcy dużych miast i aglomeracji miejskich, szczególnie z regionów ekologicznego zagrożenia, a dodatkowo tzw. klasa średnia, tj. osoby w średnim wieku o wyższych dochodach, lepiej wykształcone oraz osoby młode, uczące się o wykształceniu średnim i wyższym ${ }^{11}$.

\section{Walory przyrodnicze województwa zachodniopomorskiego istotne dla ekoturysty}

Analiza potencjału turystycznego woj. zachodniopomorskiego oraz trendów w turystyce pokazuje, że duże możliwości rozwojowe wykazuje turystyka aktywna i specjalistyczna. Jednym z typów turystyki aktywnej i specjalistycznej województwa jest ekoturystyka.

W woj. zachodniopomorskim ekoturystyka może być uprawiana w oparciu o liczne i różnorodne walory przyrodnicze, w tym kompleksy pojezierno-leśne, doliny rzeczne, wybrzeże morskie (185 km brzegu morskiego). Na terenie województwa występuje największy w Polsce zespół śródlądowych akwenów (jezioro Dąbie, Dąbie Małe, Zalew Szczeciński, Zalew Kamieński); gęsta sieć wód śródlądowych, która pokrywa $6 \%$ powierzchni regionu (tj. dwukrotnie ponad średnią dla Polski), natomiast pojezierza stanowią $35 \%$ powierzchni województwa (np. Pojezierze Drawskie, Myśliborskie, Wałeckie i Wełtyńskie). Do uprawiania ekoturystyki w woj. zachodniopomorskim zachęca także występowanie dużej ilości obszarów leśnych. Zajmują one powierzchnię ponad 8 tys. $\mathrm{km}^{2}$, (jest to ok. $35 \%$ ogólnej powierzchni regionu).

Obszarami szczególnie predestynowanymi do implementacji produktów markowych ekoturystyki w woj. zachodniopomorskim są parki narodowe i krajobrazowe, rezerwaty, obszary krajobrazu chronionego, tereny pojezierne, doliny rzeczne, tereny nadmorskie o niskim stopniu zagospodarowania gospodarczego ${ }^{12}$.

Dla ekoturysty istotna jest możliwość zwiedzenia obiektów o szczególnych walorach przyrodniczych prawnie chronionych. W woj. zachodniopomorskim

\footnotetext{
${ }^{10}$ Ekologiczny dom agroturystyczny - czyli jak nadać ekoturystyczny profil swojemu gospodarstwu, red. J. Zientek-Varga, SIĘ, Warszawa 2009.

${ }^{11}$ D. Zaręba, op. cit.

12 Strategia rozwoju turystyki w województwie zachodniopomorskim do 2015, Zachodniopomorska Regionalna Organizacja Turystyczna, Aktualizacja, grudzień 2008/sierpień 2010.
} 
w stosunku do innych województw występuje znacząca liczba zespołów przyrodniczo-krajobrazowych, zaś tylko 1 park narodowy (tab. 3).

Tabela 3

Obiekty o szczególnych walorach przyrodniczych prawnie chronione w 2012 r.

\begin{tabular}{|l|r|c|c|}
\hline \multicolumn{1}{|c|}{ Wyszczególnienie } & Polska & $\begin{array}{c}\text { Województwo } \\
\text { zachodniopomorskie }\end{array}$ & $\begin{array}{c}\text { \% udział } \\
\text { zachodniopomorskiego } \\
\text { w ogółem }\end{array}$ \\
\hline Parki narodowe & 23 & 1 & 4,3 \\
\hline Rezerwaty przyrody & 1481 & 116 & 7,8 \\
\hline Parki krajobrazowe & 122 & 5 & 4,1 \\
\hline Obszary chronionego krajobrazu & 385 & 19 & 4,9 \\
\hline Stanowiska dokumentacyjne & 161 & 10 & 6,2 \\
\hline Użytki ekologiczne & 7032 & 1171 & 16,6 \\
\hline Zespoły przyrodniczo-krajobrazowe & 328 & 42 & 12,8 \\
\hline
\end{tabular}

Źródło: opracowano na podstawie: Ochrona środowiska 2012, GUS, Warszawa 2013.

Wśród różnych rodzajów rezerwatów przyrody występujących na terenie woj. zachodniopomorskiego największy udział w porównaniu do ogólnej powierzchni kraju mają rezerwaty florystyczne, najmniejszy natomiast rezerwaty wodne. Z kolei w samym woj. zachodniopomorskim największą powierzchnię zajmują rezerwaty torfowiskowe oraz krajobrazowe, najmniejszą zaś rezerwaty wodne (tab. 4).

Tabela 4

Rezerwaty przyrody według rodzajów w Polsce i woj. zachodniopomorskim w 2012 r. (ha)

\begin{tabular}{|l|c|c|c|}
\hline \multicolumn{1}{|c|}{ Rezerwaty } & Polska & $\begin{array}{c}\text { Województwo } \\
\text { zachodniopomorskie }\end{array}$ & $\begin{array}{c}\text { \% udział } \\
\text { zachodniopomorskiego } \\
\text { w ogółem }\end{array}$ \\
\hline Faunistyczne & 43257,9 & 2025,2 & 4,7 \\
\hline Krajobrazowe & 25051,3 & 3195,6 & 12,8 \\
\hline Leśne & 66858,3 & 2739,9 & 4,1 \\
\hline Torfowiskowe & 18453,0 & 3277,5 & 17,8 \\
\hline Florystyczne & 4837,4 & 1386,0 & 28,6 \\
\hline Wodne & 4567,6 & 65,0 & 1,4 \\
\hline Stepowe & 521,1 & 83,3 & 16,0 \\
\hline Przyrody Nieożywionej & 1934,1 & 113,4 & 5,9 \\
\hline
\end{tabular}

Źródło: jak w tabeli 3.

W woj. zachodniopomorskim brak jest parków wchodzących w skład tzw. zespołów. W porównaniu do innych województw, w woj. zachodniopomorskim występuje mała ilość parków krajobrazowych. Największym parkiem jest Drawski Park Krajobrazowy, najmniejszym natomiast Park Ujście Warty (tab. 5). 
Tabela 5

Parki krajobrazowe według rodzajów w woj. zachodniopomorskim w 2012 r. (ha)

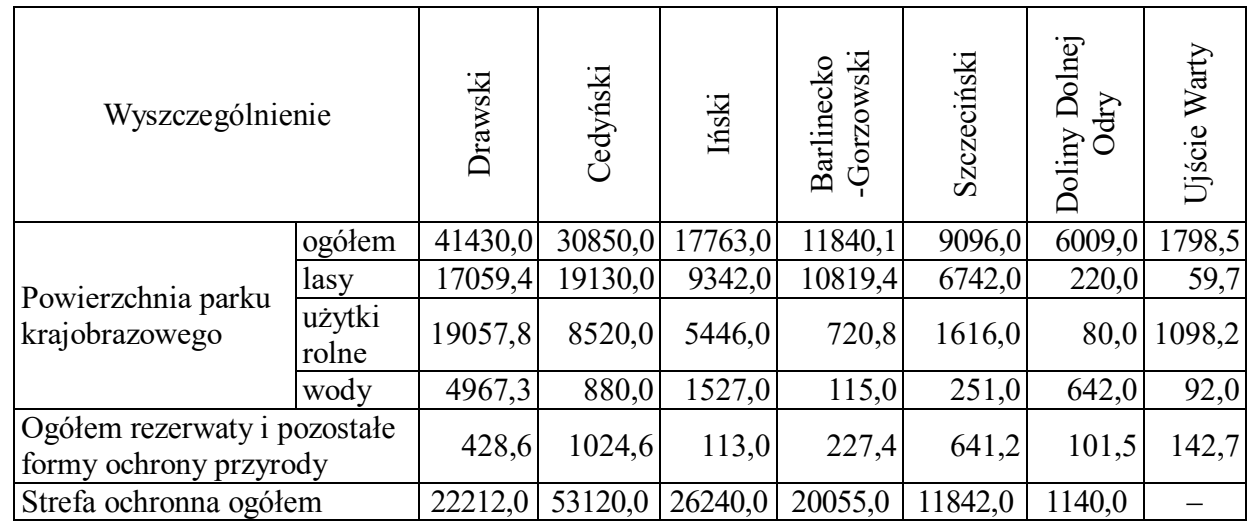

Źródło: jak w tabeli 3.

Województwo zachodniopomorskie posiada znaczącą powierzchnię terenów zaliczonych do obszarów NATURA 2000 - w szczególności są to obszary specjalnej ochrony ptaków (tab. 6). Za woj. zachodniopomorskim pod względem procentowego udziału obszarów specjalnej ochrony ptaków w powierzchni województwa plasują się województwa: podlaskie $28,7 \%$, podkarpackie $28,5 \%$, najmniejszy udział natomiast odnotowano dla województw: łódzkiego 2,2\%, opolskiego 1,5\%, świętokrzyskiego 1,9\%.

Pod względem procentowego udziału w powierzchni ogólnej województwa obszarów ochrony siedlisk woj. zachodniopomorskie plasuje się na drugiej pozycji za woj. podlaskim $(26,9 \%)$, najmniejszy udział odnotowano dla województw: opolskiego 2,9\%, lódzkiego 3,0\%.

Tabela 6

Obszary NATURA 2000 w Polsce i woj. zachodniopomorskim w 2012 r.

(\% powierzchni ogólnej)

\begin{tabular}{|l|c|c|}
\hline \multicolumn{1}{|c|}{ Wyszczególnienie } & Polska & Zachodniopomorskie \\
\hline Obszary specjalnej ochrony ptaków (OSO) & 17,8 & 30,3 \\
\hline Specjalne obszary ochrony siedlisk (SOO) & 12,2 & 18,6 \\
\hline
\end{tabular}

Źródło: jak w tabeli 3.

Województwo zachodniopomorskie nie jest bogate w pomniki przyrody. Na uwagę zasługuje liczba pojedynczych drzew stanowiąca pomniki przyrody oraz liczba głazów (tab. 7). 
Pomniki przyrody w Polsce i woj. zachodniopomorskim w 2012 r.

\begin{tabular}{|l|c|c|c|}
\hline \multicolumn{1}{|c|}{ Wyszczególnienie } & Polska & $\begin{array}{c}\text { Województwo } \\
\text { zachodniopomorskie }\end{array}$ & $\begin{array}{c}\text { \% udział zachodniopomorskiego } \\
\text { w ogółem }\end{array}$ \\
\hline Ogółem & 36316 & 2842 & 7,8 \\
\hline Pojedyncze drzewa & 29996 & 2480 & 8,3 \\
\hline Grupy drzew & 3672 & 169 & 4,6 \\
\hline Aleje & 728 & 47 & 6,5 \\
\hline Głazy & 1057 & 100 & 9,5 \\
\hline Skałki, jaskinie & 302 & 2 & 0,7 \\
\hline Pozostałe $^{\text {a }}$ & 561 & 44 & 7,8 \\
\hline
\end{tabular}

${ }^{a}$ W pozostałych: krzewy, źródła, wodospady, wywierzyska, jary, inne. Źródło: jak w tabeli 3.

Na terenie woj. zachodniopomorskiego występuja jedynie dwa ogrody botaniczne, nie ma natomiast żadnego ogrodu zoologicznego (tab. 8).

Należy zwrócić uwagę na fakt, iż w Polsce od 2005 do 2012 r. liczba ogrodów botanicznych wzrosła z 16 do 38, zaś powierzchnia z 744,2 ha do 1984 ha. Liczba ogrodów zoologicznych w tym samym okresie wzrosła z 19 do 24 .

Tabela 8

Ogrody botaniczne i zoologiczne w Polsce i woj. zachodniopomorskim w 2012 r.

\begin{tabular}{|l|c|c|c|c|}
\hline \multirow{2}{*}{ Wyszczególnienie } & \multicolumn{2}{|c|}{ Ogrody botaniczne } & Ogrody zoologiczne \\
\cline { 2 - 6 } & liczba & $\begin{array}{c}\text { powierzchnia } \\
\text { w ha }\end{array}$ & liczba & $\begin{array}{c}\text { powierzchnia } \\
\text { w ha }\end{array}$ \\
\hline Polska & 38 & 1984,0 & 24 & 616,7 \\
\hline Województwo zachodniopomorskie & 2 & 43,1 & 0 & 0 \\
\hline$\%$ udział zachodniopomorskiego w ogółem & 5,3 & - & - & - \\
\hline
\end{tabular}

Źródło: jak w tabeli 3.

Ze zwierząt chronionych w woj. zachodniopomorskim możemy spotkać bobry i wilki.

Spośród obiektów wpisanych do rejestru zabytków na terenie woj. zachodniopomorskiego najwięcej występuje obiektów dworskich oraz pałacowych i zamkowych, najmniej natomiast klasztornych i kościelnych (tab. 9).

Ekoturystyka w województwie skierowana jest głównie do osób o wyższej świadomości ekologicznej, grup młodzieżowych. Funkcjonuje ona jako wiodący produkt turystyki aktywnej na obszarach cennych przyrodniczo, natomiast na pozostałych terenach wzbogaca inne formy turystyki aktywnej. Za bazę noclegową przyjmuje się m. in. tę, będącą we własności Lasów Państwowych. Ekoturystyka w regionie przyczynia się do rozwoju np. turystyki wiejskiej i agroturystyki na obszarach cennych przyrodniczo i sąsiadujących z nimi. Aby ekoturystyka w woj. zachodniopomorskim mogła się dobrze rozwijać, konieczne jest zadbanie o wy- 
szkolenie kadry przewodników; stworzenie oferty turystycznej parków narodowych i krajobrazowych, rozwój sieci centrów edukacji przyrodniczej i ścieżek przyrodniczych, wyposażenie w profesjonalny sprzęt istniejących centrów; stworzenie bazy noclegowej o odpowiednim standardzie na/przy terenach cennych przyrodniczo. Ważne jest także przeprowadzenie inwestycji infrastrukturalnych, które winny obejmować powstanie bazy turystycznej na terenach cennych przyrodniczo (wieże i platformy widokowe, pomosty, „szałasy podglądacza” - miejsca do dyskretnej obserwacji przyrody); centra edukacji przyrodniczej ${ }^{13}$.

Parki i ogrody historyczne w Polsce i woj. zachodniopomorskim w 2012 r. - obiekty według rodzajów

\begin{tabular}{|c|c|c|c|c|c|c|c|}
\hline \multirow[b]{2}{*}{ Wyszczególnienie } & \multirow{2}{*}{ 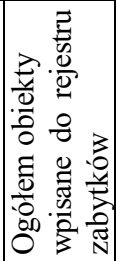 } & \multicolumn{6}{|c|}{ Obiekty według rodzajów } \\
\hline & & $\begin{array}{l}\frac{0}{2} \\
\frac{\pi}{5} \\
\frac{0}{0} \\
\frac{3}{0}\end{array}$ & 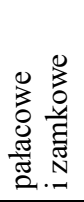 & 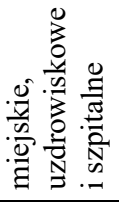 & 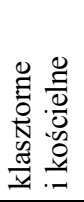 & 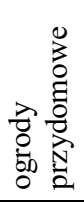 & $\stackrel{\bullet}{\Xi}$. \\
\hline Polska & 7178 & 3256 & 2102 & 255 & 108 & 637 & 820 \\
\hline Województwo zachodniopomorskie & 749 & 328 & 308 & 32 & 1 & 24 & 56 \\
\hline \% udział zachodniopomorskiego w ogółem & 10,4 & 10,1 & 14,6 & 12,5 & 0,9 & 3,8 & 6,8 \\
\hline
\end{tabular}

${ }^{\mathrm{C}}$ Łącznie: aleje, ogrody szkolne, przyfabryczne, botaniczne, arboreta, parki leśne, zieleń towarzysząca itp. Źródło: jak w tabeli 3.

\section{Podsumowanie}

Odpowiedzą turystyki na wyzwania związane z koncepcją zrównoważonego rozwoju jest rozwój turystyki zrównoważonej, w tym ekoturystyki stanowiącej jej istotną część. Taka forma turystyki jest bardziej przyjazna środowisku oraz $\mathrm{w}$ istotny sposób przyczynia się do ograniczenia negatywnych skutków wynikających z masowości turystyki. Jednym z istotnych warunków jej rozwoju, zaspokojenia potrzeb ekoturysty są walory przyrodnicze. Województwo zachodniopomorskie ze względu na swoje położenie oraz walory przyrodniczo cenne stanowi dobre miejsce do rozwijania ekoturystyki. Ekoturysta może znaleźć w regionie liczne i różnorodne walory przyrodnicze, w tym kompleksy pojezierno-leśne, doliny rzeczne, wybrzeże morskie. Konieczne jest natomiast zadbanie o stronę infrastrukturalną i poczynienie niezbędnych inwestycji, szczególnie w obszarze bazy noclegowej oraz sprzętu, który pozwalałby ekoturystom w pełni korzystać z preferowanej przez nich formy turystyki.

${ }^{13}$ Strategia rozwoju turystyki $w$ województwie zachodniopomorskim do 2015, Zachodniopomorska Regionalna Organizacja Turystyczna, Aktualizacja, grudzień 2008/sierpień 2010. 


\section{Bibliografia}

Blamey R.K., Principles of Ecotourism, w: The Encyclopedia of Ecotourism, red. D.B Weaver, Wallingford, UK, CABI Publishing 2003.

Blangy S., A few concepts and definitions, „Naturopa” 1997.

Critical issues in Ecotourism: Understanding a complex tourism phenomenon, red. J. Higham Elsevier, 2008

Diamantis D., Ladkin A., The Links Between Sustainable Tourism and Ecotourism: A definitional and operational perspective, „Journal of Sustainable Tourism” 1999, Vol. 10, No. 2

Ecotourism and other Services Derived From Forests in the Asia-Pacific Region: Outlook to 2010, FAO, www.fao.org/docrep/w7714e/w7714e00.htm\#Contents.

Ekologiczny dom agroturystyczny - czyli jak nadać ekoturystyczny profil swojemu gospodarstwu, red. J. Zientek-Varga, SIĘ, Warszawa 2009.

Kamieniecka J., (Eko) turystyka zielonym rynkiem pracy, z. 6, Instytut na rzecz ekorozwoju, Warszawa 1995.

Krippendorf J., Tourism in the system of industrial society, „Annals of tourism research” 1996, nr 13 (4), s. 517-532.

Kruczek Z., Obstuga ruchu turystycznego, Proksenia, Kraków 2004.

Kobyłko G., (red.), Proekologiczne zarzadzanie przedsiębiorstwem, Wydawnictwo Akademii Ekonomicznej we Wrocławiu, Wrocław 2000.

Machnik A., Miedzińska I., Ekoturystyka jako forma aktywizacji terenów wiejskich, w: Polityka turystyczna, red. A. Panasiuk, Fundacja na rzecz Uniwersytetu Szczecińskiego, Szczecin-Kopenhaga 2005.

Obstuga ruchu turystycznego, red. B. Meyer, Wydawnictwo Naukowe PWN, Warszawa 2006.

Ochrona środowiska 2012, GUS, Warszawa 2013.

Strategia rozwoju turystyki w województwie zachodniopomorskim do 2015, Zachodniopomorska Regionalna Organizacja Turystyczna, Aktualizacja, grudzień 2008/sierpień 2010.

Weaver D., Ecotourism as Mass Tourism: Contradiction or Reality? „Cornell Hotel and Restaurant Administration Quarterly", Ithaca, USA, Vol. 42, Cornell University 2001.

Zaręba D., Ekoturystyka, Wydawnictwo Naukowe PWN, Warszawa 2008.

\section{Meeting the ecotourist's needs by the nature of the West Pomeranian Province Summary}

The aim of this article is to show the natural values of the West Pomeranian Province essential to ecotourists. This paper describes the essence of ecotourism as the part of sustainable tourism, the tourist profile is mentioned as well as the natural values of the West Pomeranian Province. This article is based on the available references and secondary data. 